\title{
Control of the Health Risk of Radon Exposure in the Republic of Moldova
}

\author{
Liuba Coretchi $^{1}$, Antoaneta Ene ${ }^{2, *}$ (D) and Aurelia Ababii ${ }^{1}$ \\ 1 National Agency for Public Health, Nicolae Testemitanu University of Medicine and Pharmacy, \\ 67A Gh. Asachi Street, MD2028 Chișinău, Moldova; liuba.koretski@ansp.gov.md (L.C.); \\ ababiiaureliausmf@yahoo.com (A.A.) \\ 2 INPOLDE Research Center, Faculty of Sciences and Environment, Dunarea de Jos University of Galati, \\ 47 Domneasca Street, 800008 Galati, Romania \\ * Correspondence: Antoaneta.Ene@ugal.ro
}

Citation: Coretchi, L.; Ene, A.;

Ababii, A. Control of the Health Risk of Radon Exposure in the Republic of Moldova. Atmosphere 2021, 12, 1302. https://doi.org/10.3390/

atmos12101302

Academic Editor: Cucoş

(Dinu) Alexandra

Received: 15 September 2021

Accepted: 5 October 2021

Published: 7 October 2021

Publisher's Note: MDPI stays neutral with regard to jurisdictional claims in published maps and institutional affiliations.

Copyright: (c) 2021 by the authors. Licensee MDPI, Basel, Switzerland. This article is an open access article distributed under the terms and conditions of the Creative Commons Attribution (CC BY) license (https:// creativecommons.org/licenses/by/ $4.0 /)$.

\begin{abstract}
The paper presents the results of a national radon survey conducted in the context of the Republic of Moldova. The study included about 2500 homes of different types, located in urban and rural localities in different areas of the country. The RADTRAK2 detectors kindly provided by the RADONOVA laboratory, Uppsala, Sweden, for the MOL9007 project funded by the International Atomic Energy Agency (IAEA) have been used. The exposure period was 90 days. The measured radon concentrations are the following: the average ( \pm standard deviation) $252.8 \pm 215.9 \mathrm{~Bq} / \mathrm{m}^{3}$; the range (minimum-maximum) $10-1480 \mathrm{~Bq} / \mathrm{m}^{3}$; the median $200 \mathrm{~Bq} / \mathrm{m}^{3}$ and the geometric mean ( \pm geometric standard deviation) $158.5 \pm 3.0 \mathrm{~Bq} / \mathrm{m}^{3}$. The results of the study allowed mapping indoor radon and identifying localities with increased radon concentrations. In order to reduce the high radon concentrations in places recording $>300 \mathrm{~Bq} / \mathrm{m}^{3}$, appropriate measures have been proposed according to the legislation in force. The cluster analysis showed positive links between the radon concentration in dwellings and the incidence of respiratory diseases, especially the bronchopulmonary cancer in the country.
\end{abstract}

Keywords: radon; risk assessment; dwellings; Republic of Moldova

\section{Introduction}

The exposure of the population to natural radioactive sources is primarily due to radon $\left({ }^{222} \mathrm{Rn}\right)$, which constitutes over $50 \%$ of the total exposure [1]. Radon can penetrate houses due to the difference in pressure in the building and its foundation in the soil. Gas migrates through cracks in the walls, drains, communication pipes, building materials and drinking water [2]. Radon is a noble, radioactive gas present in soil, with a half-life of 3.8 days by the alpha decay. It is colorless, odorless, tasteless and naturally originates in rock and soil. Radon decay products, also being radioactive, are called the descendants of radon and include ${ }^{218} \mathrm{Po},{ }^{214} \mathrm{~Pb},{ }^{214} \mathrm{Bi}$ and ${ }^{214} \mathrm{Po}$. Radon moves freely in the air and can be inhaled. It is quickly exhaled, but its decay products can settle in the lung, where they continue to undergo radioactive decay and give a dose of radiation to the lung tissue [2].

Radon is produced in the soil by the radioactive decay of radium $\left({ }^{226} \mathrm{Ra}\right)$ in the decay chain of uranium $\left({ }^{238} \mathrm{U}\right)$. Both ${ }^{226} \mathrm{Ra}$ and ${ }^{238} \mathrm{U}$ are present in different concentrations in most rocks and soils. Radon is continuously exhalated from the soil into the open air, where it is quickly diluted to harmless concentrations. When radon enters an enclosed space, such as a building, it can be accumulated and pose a possible health risk. Radon migrates from the soil to the building through the cracks in the foundation and walls or through the water and sewerage network and gradually accumulates in the indoor air.

A number of factors are of particular importance for examining the problem of radon indoor pollution: the type of soil, the location of the housing area, the number of levels of the dwelling and the building materials used. The main sources of radon in the dwellings 
are in the order of importance: the exhalation of radon from the soil, the emanation from building materials - components of the dwelling, the water used for washing/cooking, as well as the gas used in kitchens or stoves for heating [2].

Although the concentration of radon is closely related to the concentration of uranium in soil, its presence in traces in all soil types contributes to the resident population's exposure. The problem of radon diffusion from the soil through the house foundations is associated with the emission of radon from building materials, thus causing intense pollution of indoor air. The process of emission is dependent on two factors: the presence of radium in the structure of materials, along with the radon emanation coefficient, and the second is the type and microstructure of the building elements on which the release of radon depends, a phenomenon conditioned by moisture. The highest radium contents are found in brick, followed by concrete, sandstone and faience, and the smallest quantities are in wood [2].

\subsection{What Is the Harmfulness of Radon?}

This ubiquitous gas is responsible for the effects on the mitotic apparatus, cellular and nuclear components, thus being involved in the etiology of oncological diseases. International studies point out that for radon exposure with a concentration of $200 \mathrm{~Bq} / \mathrm{m}^{3}$, the estimated risk is $2.98-6.55 \%$ for smokers and $0.19-0.42 \%$ for non-smokers under the conditions of a multiplicative relationship for the common effect of radon and smoking [3].

The contribution of radon and thoron in the internal and external exposure of the population consists in the fact that they produce a whole number of other radioactive isotopes on the one hand, and on the other hand, inert gases can reach any part of the body, being especially involved in affecting the respiratory system [4].

Radon is considered a toxic substance in the environment and poses health risks, which has led to increased awareness of the population, with extensive research being carried out on the assessment of the concentration of radon in homes [3,4]. Indoor radon increases the risk of developing bronchopulmonary cancer, positioning itself in second place after active smoking, which is the highest risk of developing lung cancer. More than $85 \%$ of deaths from bronchopulmonary cancer are among smokers [3-5]. A tobacco control policy is the most promising direction in achieving public health objectives in terms of radon exposure control [3].

Recently conducted epidemiological and ecological studies demonstrate the radon's impact on the development of bronchopulmonary cancer. The risk increases depending on the duration of exposure and the concentration of radon. Total exposure to radon consists of exposure in homes, at school, at work and in leisure establishments in the free time [6,7].

The study, through statistical models applied to the most recently published data in the field of estimating the incidence and mortality for 25 major cancers, carried out in 40 countries of the European Union to 2018, demonstrated important results [8]. Thus, 3.91 million new cases of cancer (excluding non-melanoma skin cancer) and 1.93 million deaths caused by cancer in Europe have been estimated. The most common cancers were: breast cancer $(523,000$ cases), followed by colorectal cancer $(500,000)$, lung cancer $(470,000)$ and prostate cancer $(450,000)$. These four types of cancer account for half of the total burden of cancer in Europe. The most common causes of death from cancer were lung cancer $(388,000$ deaths), colorectal $(243,000)$, breast $(138,000)$ and pancreatic cancer $(128,000)$. The estimated number of new cases of oncological diseases was about 1.6 million for men and 1.4 million for women, with 790,000 deaths for men and 620,000 for women [8]. The organization of the radon exposure risk communication system [9-11] is of interest.

\subsection{Mechanisms of Development of Tumor Processes as a Result of Exposure to Radon and Tobacco}

Radon, by altering the processes of translation and transcription at the cellular level, is a trigger factor in the action of tobacco at the level of the respiratory apparatus, especially in people whose health status is compromised by the presence of chronic pathology. Nicotine prevents the processes of cellular apoptosis by increasing the activity of acetyl-choline; thus, 
cells exposed to significant doses of alpha (radon) radiation and which have accumulated certain mutations will not self-destruct but can evolve into tumor processes. Synergism between radon and tobacco with a cumulative tendency causes massive damage to the alveolar tissue [1,2,12].

The distribution of the incidence of bronchopulmonary cancer at regional and continental levels is influenced by the variability of smoking and the dispersion of radon concentrations in housing. Of particular importance in addressing the tobacco problem is the exposure of non-smokers to cigarette smoke and its effects on general health. Former smokers are of interest as an object of study because, according to the analyses carried out at an international level, the risk related to the occurrence of lung cancer associated with radon is about $5-7$ times higher than in non-smokers. The interaction between cigarette smoke and radon should be treated from the perspective of other non-chemical stressors of the lifestyle, which would allow consolidating the results of synergism between them. Studies show that there was no gender difference in the risk of lung cancer caused by radon for certain categories of smokers [1-3].

The purpose of the research was to estimate the risk to health associated with exposure to radon in homes in the Republic of Moldova and the elaboration of measures to control, reduce and prevent the influence of the radiostress factor on health in the context of the directive EURATOM/59/2013 [13].

\section{Materials and Methods}

\subsection{Study Objectives}

The objectives of the study were: elaborating on the guide for placing passive detectors in homes; evaluating the characteristics of the dwelling and the population's knowledge regarding the impact of radon on health; measuring the radon concentration in the indoor air of 2500 dwellings by using passive detectors; reading the results of radon concentrations in the RADONOVA Laboratory, Uppsala, Sweden; statistical analysis of the obtained results; mapping radon concentrations in the air of dwellings in the territory of the Republic of Moldova with the identification of the country's localities with high radon risk.

The hypothesis of the research was the confirmation/refutation of the existence of danger to health as a result of the exposure of the population to radon in the air in homes.

\subsection{Methodology}

The air of 2500 dwellings of different types in both rural and urban areas of the main areas of the Republic of Moldova (North, Center and South) served as the study material.

\subsubsection{The Criterion for Selecting the Concentration Measurement Sites of ${ }^{222} \mathrm{Rn}$}

The sites for measuring the concentration of ${ }^{222} \mathrm{Rn}$ in the indoor air were selected randomly directly from the areas included in the study—North, Center and South—according to the EC methodology. The measurement was made mainly on the ground floor, in the bedroom or the room for guests. Data on the construction of dwellings (new or old type), the year of construction, the type of building and finishing materials used, the address and the presence/lack of foundation were examined after being obtained from questionnaires filled in by the dwelling owners. The measurements were made with long-lasting passive detectors RADTRAK2, and the exposure period was 90 days (Figure 1). 

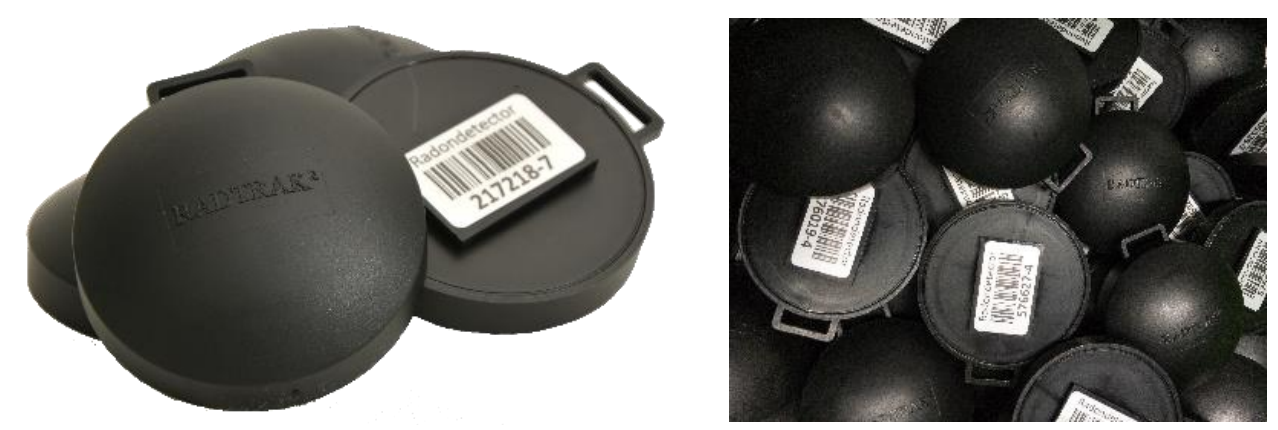

Figure 1. RADTRAK2 detector for measuring concentrations of ${ }^{222} \mathrm{Rn}$ in homes in long-term-from 2 months to 1 year.

\subsubsection{Evaluation of the Characteristics of the Dwelling}

In order to evaluate the characteristics of the studied dwellings, a questionnaire was elaborated, which was completed by the owners of the dwellings $(n=2500)$, where they described the type of house:

- individual dwelling on the ground, public dwelling or public building, year of construction, about the existence of the concrete foundation;

- type of floor (wood, solid parquet, tiles, laminate flooring, other);

- the materials from which the walls are built (reinforced concrete, brick, stone, wood, adobe, other);

- $\quad$ type of ceiling (reinforced concrete, wood, other);

- $\quad$ type of windows (simple, double glazing);

- $\quad$ presence of cracks (yes/no);

- artificial ventilation (no ventilation, fan, air conditioning).

The analysis of the questionnaires showed that 1147 investigated dwellings were in the urban area and 1287 in the rural area. Most of the houses in the rural area were located directly on the ground without a concrete foundation. In such homes, radon usually penetrates the soil more easily.

2.2.3. Evaluation of the Population's Knowledge Regarding the Impact of Radon on Health

The aim of this study was to outline the main objectives for developing a strategy for risk communication on radon exposure based on the public survey. The direct questioning and the use of the online internet questionnaire for the 300 residents of the Republic of Moldova in order to assess their perceptions and level of knowledge about radon was conducted as a reference point for assessing public awareness.

The survey found a relatively small number of people who know nothing about radon, the risk of its effects and measures to control and prevent radon exposure. Most respondents have diverse, though not always correct, knowledge about the health risks of radon (Table 1). Based on the obtained responses, several areas have been proposed for the focus of future studies: obtaining broad organizational support and determining the need for risk communication; creating risk communication objectives with key messages for different target groups; evaluation of stakeholders and communication channels; strengthening stakeholders to gain knowledge about radon in different target groups; elaboration of the national program for risk communication of radon exposure. 
Table 1. Questionnaire regarding the health risk as a result of radon exposure used in the Republic of Moldova.

\begin{tabular}{|c|c|c|}
\hline \multicolumn{2}{|c|}{ Questions and Answers about Health Risk } & Respondents, \% \\
\hline \multirow{7}{*}{$\begin{array}{c}\text { What happens if the radon level is } \\
\text { increased in the rooms? }\end{array}$} & Feeling sick & 34.8 \\
\hline & Suffocation & 8.1 \\
\hline & Disorders & 21.3 \\
\hline & Dizziness & 17.2 \\
\hline & $\begin{array}{l}\text { It affects the respiratory } \\
\text { system, including } \\
\text { bronchopulmonary cancer }\end{array}$ & 66.6 \\
\hline & Do not know & 12.2 \\
\hline & Other & 1.0 \\
\hline \multirow{4}{*}{$\begin{array}{c}\text { Does radon inhaled with air in rooms } \\
\text { influence the appearance of } \\
\text { bronchopulmonary cancer or other } \\
\text { cancers? }\end{array}$} & Yes & 83.4 \\
\hline & No & 0.7 \\
\hline & Do not know & 15.5 \\
\hline & Other & 0.3 \\
\hline \multirow{7}{*}{$\begin{array}{l}\text { What are the consequences of chronic } \\
\text { radon exposure? }\end{array}$} & $\begin{array}{c}\text { Triggering of } \\
\text { bronchopulmonary cancer }\end{array}$ & 80.4 \\
\hline & $\begin{array}{l}\text { Triggering of other diseases of } \\
\text { the respiratory system }\end{array}$ & 19.6 \\
\hline & Nervous system disorders & 11.1 \\
\hline & Cardiovascular diseases & 7.4 \\
\hline & Digestive disorders & 2.0 \\
\hline & Do not know & 13.9 \\
\hline & Other & 0.3 \\
\hline \multirow{6}{*}{$\begin{array}{l}\text { More often, what type of cancer can } \\
\text { cause radon exposure? }\end{array}$} & Lung & 85.5 \\
\hline & Duodenum & 2.0 \\
\hline & Cutaneous & 2.7 \\
\hline & Osseous & 2.0 \\
\hline & Do not know & 12.2 \\
\hline & Other & 0.0 \\
\hline
\end{tabular}

2.2.4. Methodology for Building the Radon Map in Housing in the Republic of Moldova

For the production of the radon map, the grid defined in the Lambert-GISCO system by the Joint Research Center (JRC) of the European Commission was used. According to the established grid, the map of the Republic of Moldova is represented by 336 cells with sides of $10 \times 10 \mathrm{~km}^{2}$. For each cell in the reference grid, we calculated: the number of measurements, the arithmetic mean, the arithmetic mean of the logarithmic values, the standard deviation, the standard geometric deviation, the median, the minimum value and maximum value. The grouping of the results and their rendering through certain color codes was made based on the values recommended by the European Commission. In order to compare and integrate these results into the European radon map, it is necessary to use the frequency classes provided by the JRC. 


\section{Results}

During the period of study, the research was focused on the elaboration of the new methodology for investigating indoor radon through long-term measurement methods. This methodology was used in the measurement of ${ }^{222} \mathrm{Rn}$ in the indoor air of different types of dwellings $(n=2500)$ in rural and urban areas of the main areas of the Republic of Moldova. RADTRACK2 detectors, offered by the IAEA within the Technical Cooperation Project MOL9007 "Elaboration of the National Program (Strategy and Action Plan) of the control of the exposure of the population of the Republic of Moldova to radon", were placed in bedrooms/guesthouses for a period of about 90 days.

In order to carry out the investigations/survey of radon concentrations by long-term methods, the following requirements/methodologies have been developed (approved at the meeting of the SCIENTIFIC COUNCIL of the National Agency for Public Health (ANSP) of Moldova from 11 June 2019, extract from the minute no. 4):

- The requirements for placing detectors in the dwelling;

- Questionnaires for the identification of housing conditions/type;

- The agreement between radon investigators and the owner of the dwelling;

- The questionnaire for the evaluation of the population's knowledge regarding radon.

The elaborated materials, together with the detectors, were distributed to the chief physicians of the regional CSP $(n=10)$ during the Workshop organized by the ANSP on 4 February 2019.

In June 2019 (the exposure period was 90 days), the detectors were collected and dispatched to the RADONOVA laboratory in Sweden for reading the information (concentration of ${ }^{222} \mathrm{Rn}$ ), which was retransmitted in 2 weeks to the Radiation Hygiene and Radiobiology Laboratory of ANSP.

The research results have shown that the activity of ${ }^{222} \mathrm{Rn}$ varied depending on: the type and location of the dwellings, the type of building materials, the type of soil adjacent to the building and the ventilation of the rooms.

Table 2 shows the distribution of data of radon concentrations in the air in homes located in the territory of the Republic of Moldova. The results show that in about 1170 dwellings out of those investigated, i.e., in $49 \%$ dwellings, the concentration of radon corresponds to national/European norms.

Table 2. Results of the radon concentration measurement with RADTRAK2 detectors (passive measurement, exposure period 90 days) in 2447 dwellings in rural and urban areas of the Republic of Moldova, in 2019.

\begin{tabular}{cccc}
\hline No. & Radon Concentration, Bq $/ \mathbf{m}^{\mathbf{3}}$ & Number of Houses & \% \\
\hline 1 & Up to 150 & 1170 & 49 \\
\hline 2 & $160-290$ & 615 & 25 \\
\hline 3 & $300-490$ & 338 & 13.52 \\
\hline 4 & $500-790$ & 251 & 10.04 \\
\hline 5 & $800-990$ & 58 & 2.3 \\
\hline 6 & $>1000$ & 15 & 0.6 \\
\hline
\end{tabular}

At the same time, in 615 dwellings (25\%), the concentration of radon was higher than the national norms; in 662 dwellings (26\%), the concentration of radon was higher than the European norms. In 1277 dwellings (51\%), the concentration of radon was higher than the national/European norms. The results indicate the existence of a radon problem in housing in the territory of the country and the need to solve it. In connection with the above-mentioned information, the draft Government Decision "On the approval of the National Strategy on the reduction of the risk associated with natural irradiation, including radon" was elaborated and sent to the Ministry of Health, Labor and Social Protection for 
approval. The draft GD stipulates the need to elaborate and carry out amendments to the Construction Code with the need to monitor radon when putting the dwellings into use. At the same time, it is strictly necessary to monitor radon in the soils on which the building will be located. In neighboring countries such requirements are already implemented.

The study of the variability of radon concentrations according to the geographical coordinates of the localities was of interest. An imposing variability was established for this parameter, ranging from $151.6 \mathrm{~Bq} / \mathrm{m}^{3}$ in Chisinau to $419.5 \mathrm{~Bq} / \mathrm{m}^{3}$ in Căușeni (Figure 2). This fact can be explained by the uneven geology of the territory.

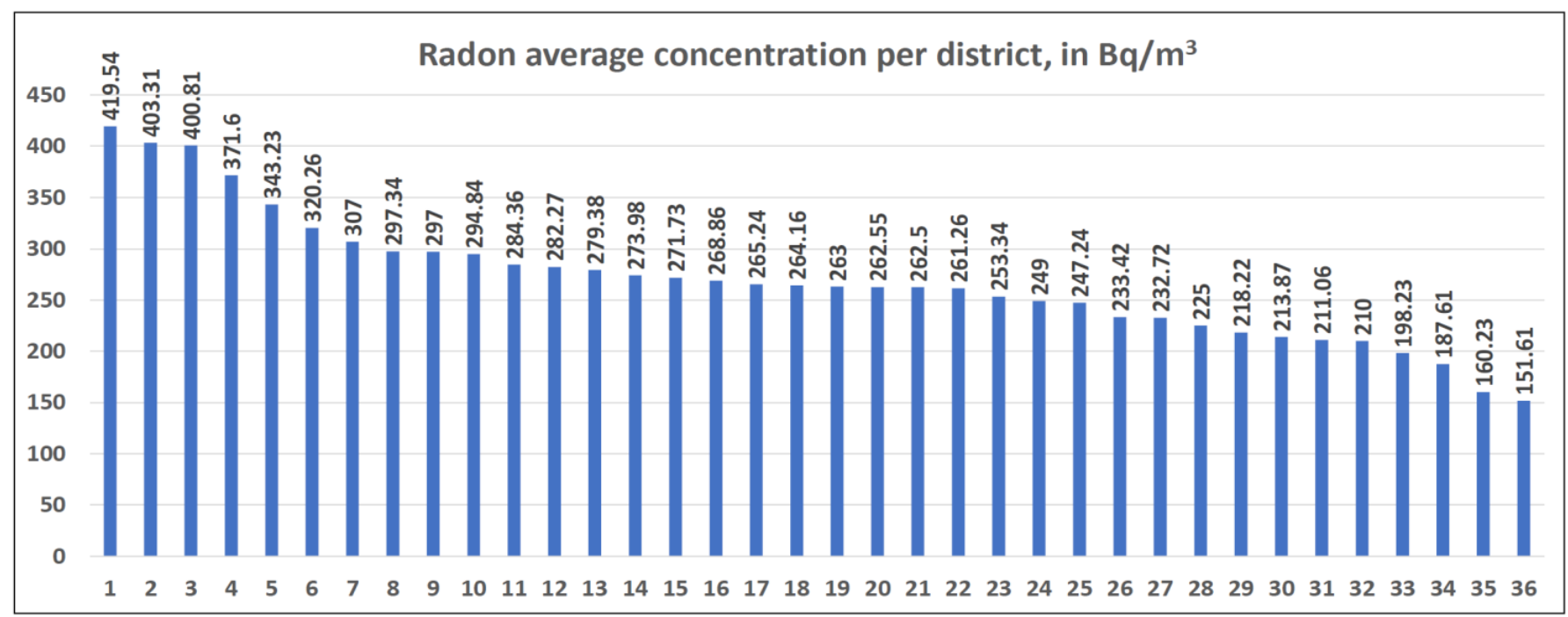

Figure 2. Variability of radon concentration in the indoor air of dwellings placed in different geographical districts of the Republic of Moldova, year 2019. 1-Căușeni, 2-Comrat, 3-Vulcănești, 4-Ceadîr Lunga, 5-Ștefan-Vodă, 6-Nisporeni, 7-Leova, 8-Hîncești, 9-Telenești, 10-Cimișlia, 11-Glodeni, 12-Basarabeasca, 13-Cantemir, 14-Edineț, 15-Bălți, 16-Cahul, 17-Drochia, 18-Florești, 19-Soroca, 20-Călărași, 21-Taraclia, 22-Sîngerei, 23-Criuleni, 24-Rezina, 25Strășeni, 26-Ungheni, 27-Ialoveni, 28-Șoldănești, 29-Anenii-Noi, 30-Ocnița, 31—Dondușeni, 32-Orhei, 33-Briceni, 34-Fălești, 35-Rîșcani and 36-Chișinău municipality.

The research has shown that the concentration of radon in dwellings in urban and rural areas of the Republic of Moldova varied depending on the area. Thus, in the Southern area, the average value of the radon concentration was the highest detected, $330.3 \mathrm{~Bq} / \mathrm{m}^{3}$, followed by the Center-253.8 Bq/ $\mathrm{m}^{3}$ and the North area-237.9 Bq $/ \mathrm{m}^{3}$ (Figure 3).

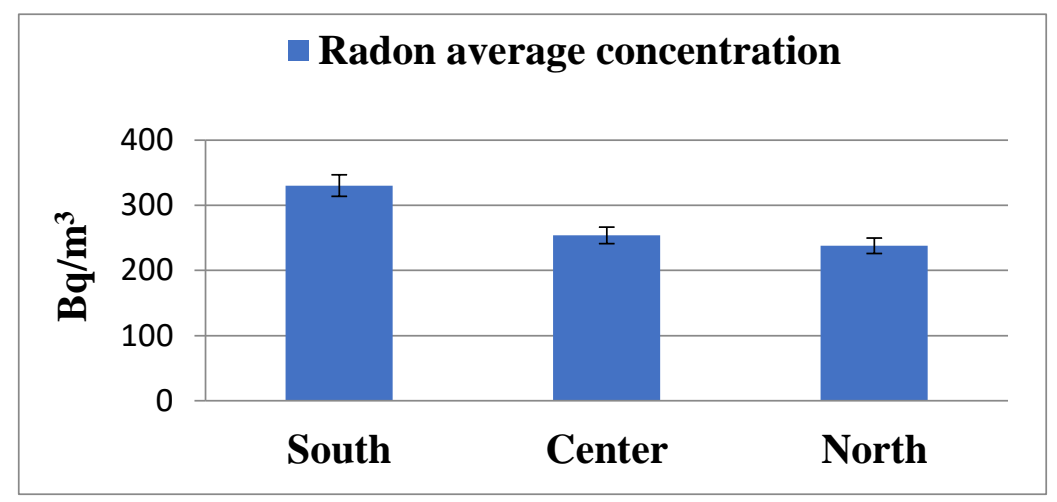

Figure 3. Variability of radon concentration in the Republic of Moldova depending on the area: South, Center and North; year 2019 ( $n=2435$ total valid measurements with RADTRAK2 detectors, exposure period 90 days). The error bars indicate a $5 \%$ standard deviation of the data sets. 
At the same time, the variability of radon concentration in the air in dwellings located in the territory of the Republic of Moldova, depending on the locality type (rural or urban), was analyzed. The research shows that the average indoor radon concentration was higher in rural areas, constituting $261.6 \mathrm{~Bq} / \mathrm{m}^{3}$, compared to urban ones-243 Bq/ $\mathrm{m}^{3}$. As a matter of fact, village houses are commonly located directly on the ground or have inadequate foundation slabs. These conditions allow the radon from the soil/rocks to more easily penetrate the living room (Figure 4).

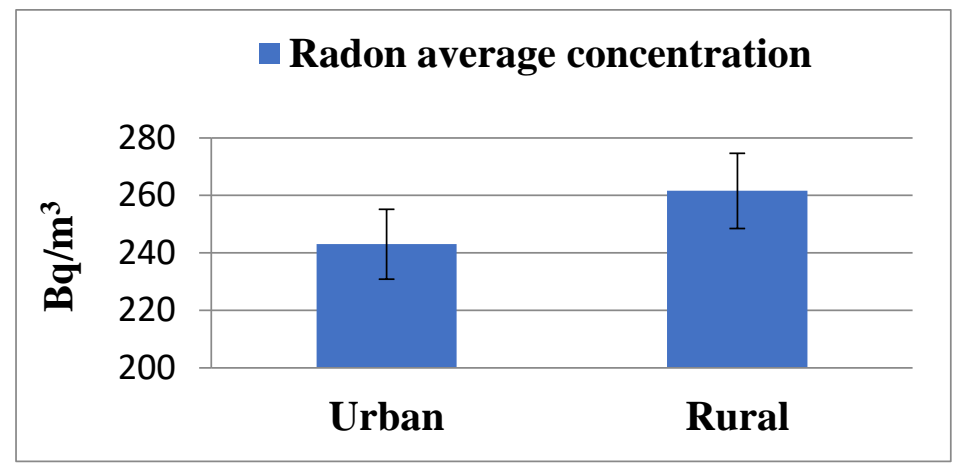

Figure 4. Concentration of radon in the air of homes, in rural and urban localities of the Republic of Moldova, year 2019 ( $n=2435$ valid measurements with RADTRAK2 detectors, exposure period 90 days). The error bars indicate a $5 \%$ standard deviation of the data sets.

Based on the analysis of the results of the measurement of the radon concentration in the indoor air of dwellings (valid number $n=2435$ ) by using RADTRAK2 passive detectors, it was established that the arithmetic mean of the index was $252.8 \mathrm{~Bq} / \mathrm{m}^{3}$, and the standard deviation of the mean-215.9 Bq/ $\mathrm{m}^{3}$. Descriptive statistics of the dataset from the national indoor radon survey (entire territory, urban and rural areas), performed using appropriate tools provided by the Microsoft Excel 2019, is presented in Table 3, including arithmetic mean (Average) with standard deviation (SD), minimum (Min), maximum (Max), median, geometric mean (GM) and geometric standard deviation (GSD).

Table 3. Descriptive statistics of the dataset from the national indoor radon survey in 2019.

\begin{tabular}{ccccccccc}
\hline \multirow{2}{*}{ Region } & \multicolumn{8}{c}{ Variable } \\
\cline { 2 - 9 } & Valid $n$ & Average & SD & Min & Max & Median & GM & GSD \\
\hline Republic of Moldova & 2435 & 252.8 & 215.9 & 10 & 1480 & 200 & 158.5 & 3.0 \\
\hline Urban area & 1147 & 243.0 & 225.9 & 10 & 1260 & 170 & 140.3 & 3.3 \\
\hline Rural area & 1287 & 261.6 & 206.2 & 10 & 1480 & 220 & 176.9 & 2.8 \\
\hline
\end{tabular}

Based on the results obtained, using Google maps, ARCGIS and other programs, the mapping of radon on the territory of the country was carried out (Figure 5). The results were submitted to the Joint Research Commission (JRC) and included on the European radon map [14]. 


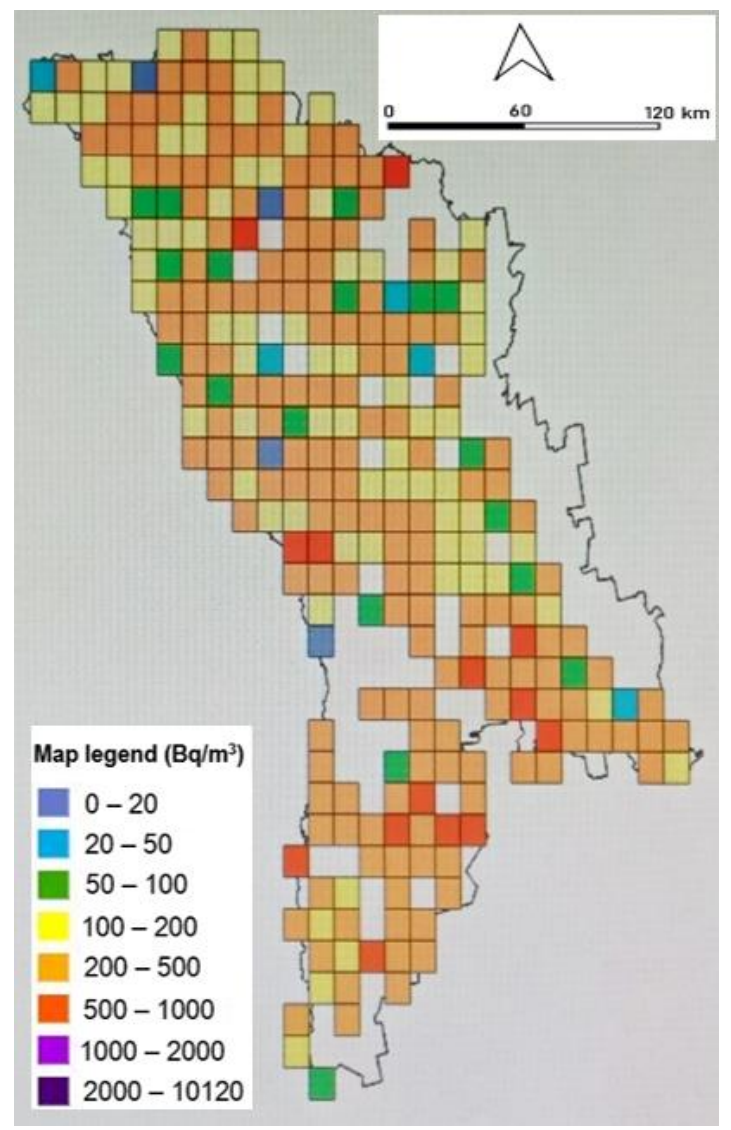

Figure 5. Mapping radon in the air of various types of housing, in rural and urban areas, in the Northern, Central and Southern areas of the Republic of Moldova. The radon concentration ranges specified in the map legend are in accordance with the European radon map, Joint Research Commission [14].

\section{Discussion}

In accordance with the "Fundamental Norms of Radiation Protection, Requirements and Hygienic Rules" (NFRP-2000) and "Regulation and Hygienic Rules on the Regulation and Hygienic Norms on the Regulation of Radiation Exposure of the Population from Natural Sources", the national reference level of ${ }^{222} \mathrm{Rn}$ was set at a concentration of $100 \mathrm{~Bq} / \mathrm{m}^{3}$ for new buildings and $150 \mathrm{~Bq} / \mathrm{m}^{3}$ for existing buildings [15,16].

In the case higher concentrations (above $200 \mathrm{~Bq} / \mathrm{m}^{3}$ ) were detected, radioprotection measures should be taken to reduce the penetration of ${ }^{222} \mathrm{Rn}$ into the air of dwellings and to improve the ventilation of the rooms. The displacement of tenants (with their consent) and the reshaping of rooms, buildings may take place in cases where it is impossible to reduce the average annual equilibrium activity concentration of ${ }^{222} \mathrm{Rn}$ to values lower than $300 \mathrm{~Bq} / \mathrm{m}^{3}[16]$.

It should be noted that the above-mentioned values were set a priori, not based on measurements. Recently, in the period 2018-2019, as a result of the implementation of the national project MOL9007 funded by the IAEA, the results being presented in the work in question, it was noticed that in 1277 dwellings (51\%), the concentration of radon was higher than the reference values set in national/European norms. Based on these results, it was proposed to modify the national reference value at $300 \mathrm{~Bq} / \mathrm{m}^{3}$ in the near future.

Cluster Analysis of the Interaction of Factors "Concentration of Radon $\times$ Incidence/Prevalence of Diseases of the Respiratory System and Hemoblastoses"

Among the effects of exposure to natural ionizing radiation is carcinogenesis. Radon is the main component of natural ionizing radiation sources. In the Republic of Moldova, tumors are the second leading cause of death [17]. The most diagnosed malignant tumors 
in the country are breast and bronchopulmonary cancer. Figure 6 presents the structure of morbidity due to oncological diseases in the period 2014-2016, based on the processing of the raw data published in the study [17], which was elaborated in the frame of a national project in the context of directive EURATOM/59/2013.

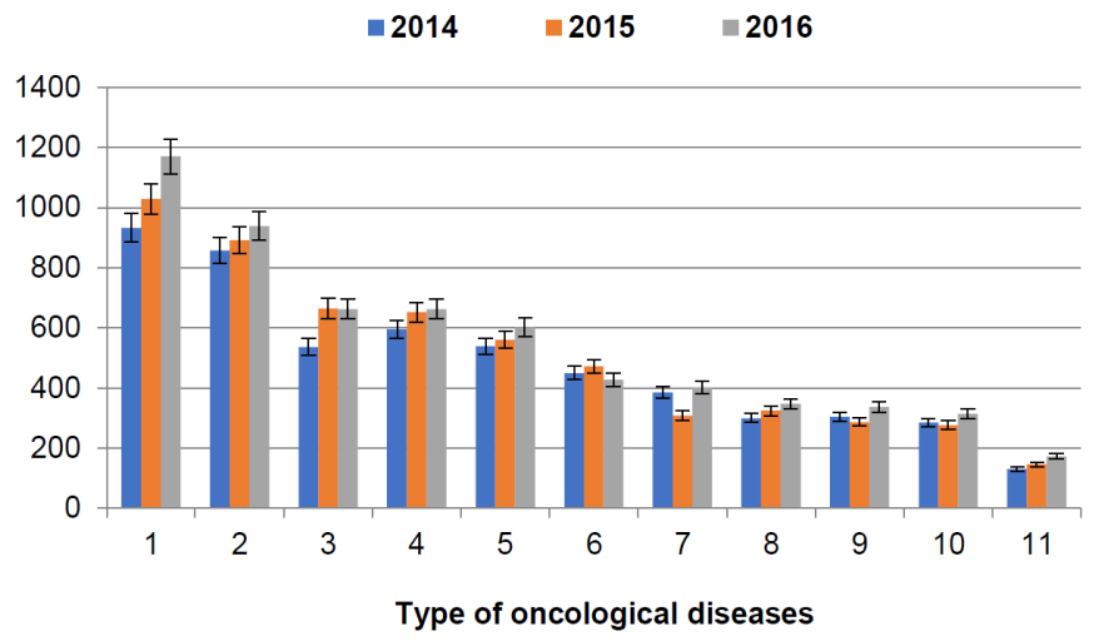

Figure 6. The structure of morbidity due to oncological diseases (absolute cases) in the period 20142016 in the Republic of Moldova; 1-bronchopulmonary cancer, 2-mammary gland, 3-rectum, 4-stomach, 5-colon, 6-hemoblastosis, 7-cervix, 8-uterus, 9-liver, 10-thyroid gland and 11 -ovary.

Through the cluster analysis (CA), the interactions within the relationship "radon concentration $\times$ incidence/prevalence of non-communicable diseases" (Figure 7) were established.

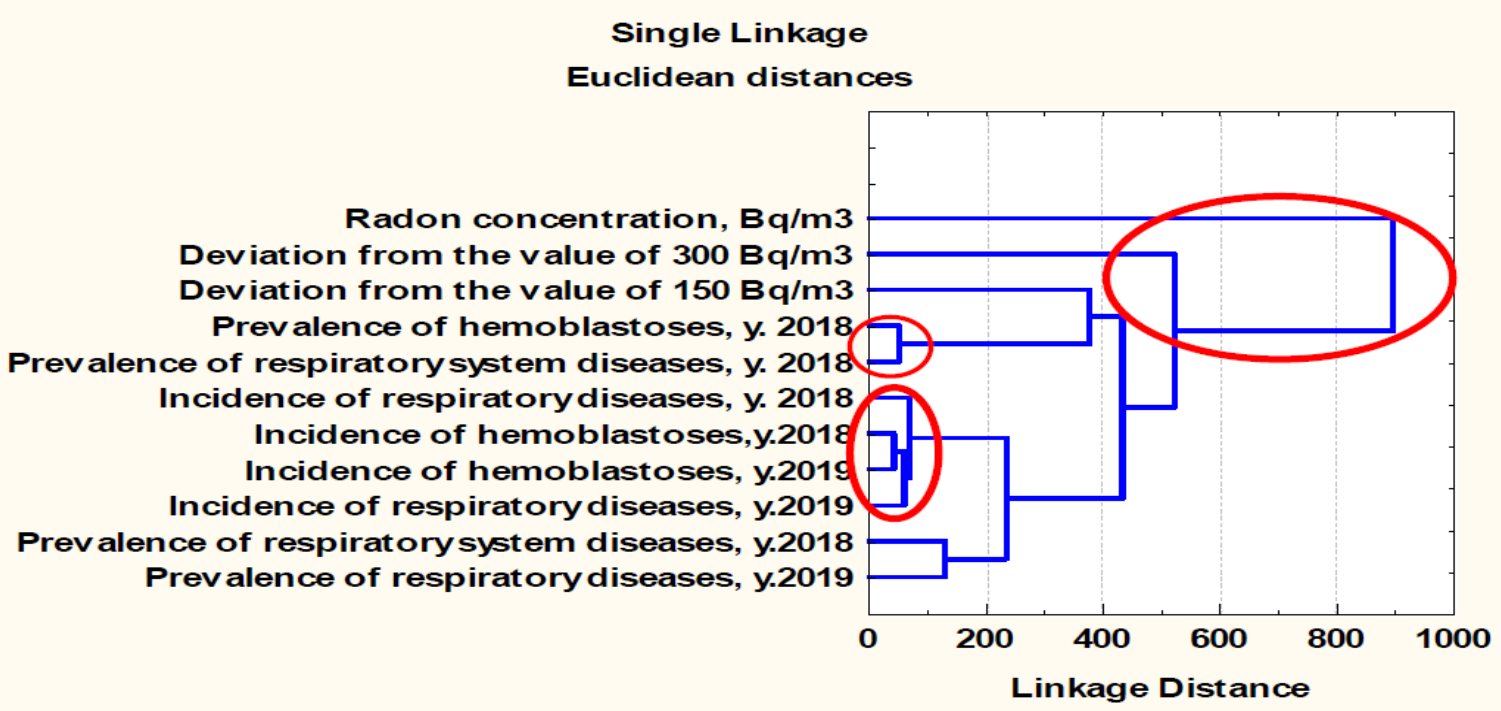

Figure 7. Cluster analysis of the interaction of factors "Concentration of radon $\times$ incidence/prevalence of diseases of the respiratory system and hemoblastoses".

By highlighting the Euclidian distances and linkages, the CA also demonstrates the interaction between the radon action and the prevalence of oncological diseases, especially bronchopulmonary cancer (cluster A in Figure 8). The overlapping of maps of the incidence of bronchopulmonary cancer [17] and radon concentrations on the territory of the country has demonstrated relationships of partial interaction of these two factors, which denotes that the onset of bronchopulmonary cancer under the action of radon is a cumulative effect 
determined by long-term chronic exposure and also influenced by other factors, such as smoking, exogenous factors, etc. Additionally, the research is continuing (Figure 9). Thus, through controlled epidemiological studies, it is possible to demonstrate the interaction between radon $\times$ bronchopulmonary cancer.

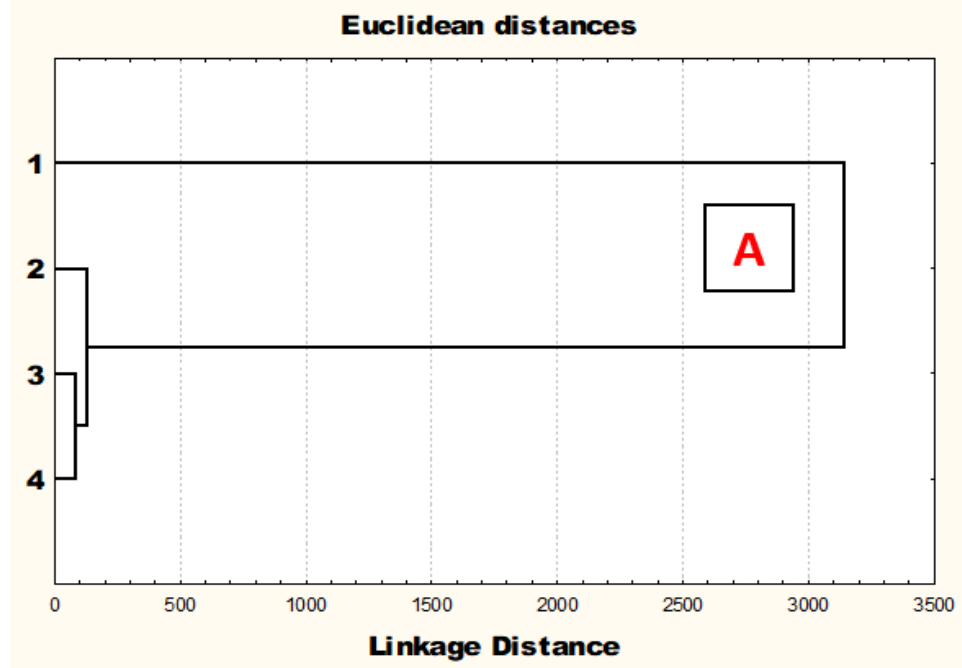

Figure 8. Cluster analysis of radon $\times$ oncological maladies interaction; 1 -radon concentration, 2 incidence of bronchopulmonary cancer, 3 -incidence of hemoblastoses and 4-incidence of thyroid gland cancer. The most important cluster, labeled as A, shows a significant linkage between radon and bronchopulmonary cancer.

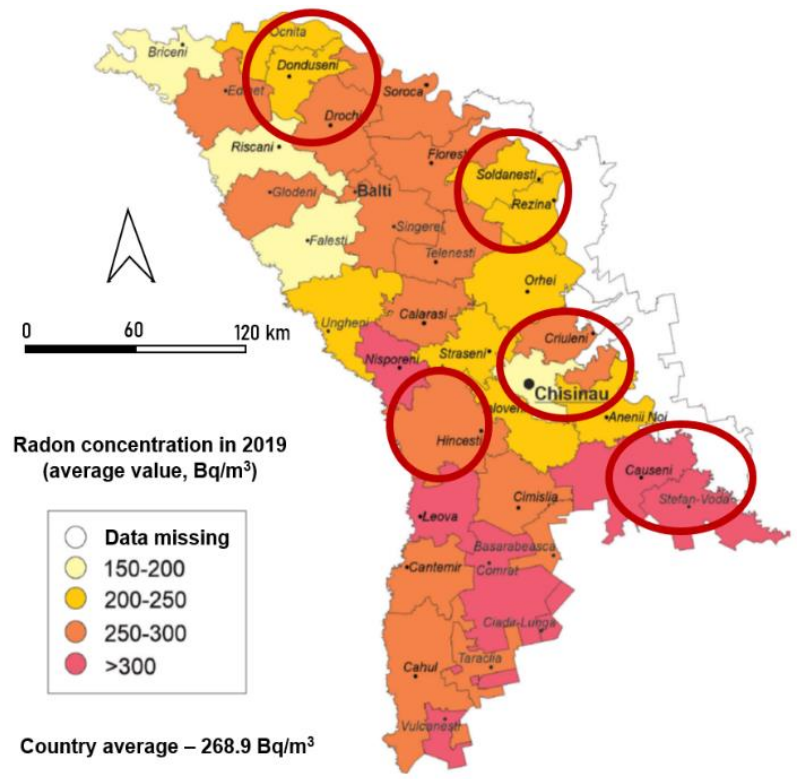

(a)

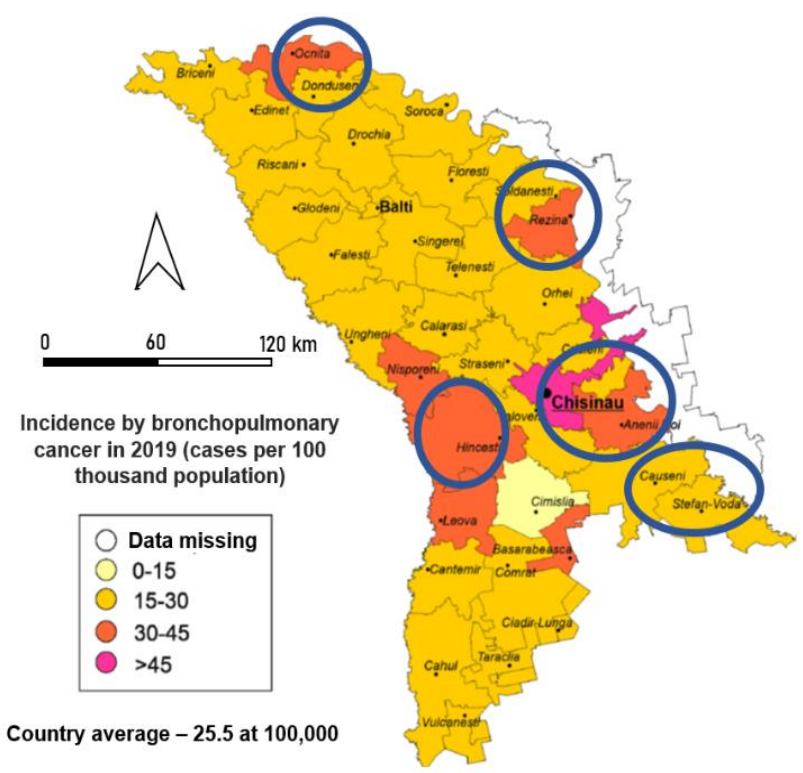

(b)

Figure 9. Radon concentration $\left(\mathrm{Bq} / \mathrm{m}^{3}\right)(\mathbf{a})$ and incidence by bronchopulmonary cancer (cases per 100 thousand population) (b).

\section{Conclusions}

1. Radon concentrations were monitored in the air of different types of dwellings $(n=2500)$ located in rural and urban localities of different areas of the Republic of Moldova using long-term alpha detectors of the RADTRAK2 type with an exposure period of 90 days. The monitoring established the variability of the indicator 
depending on the geographical area, abiotic conditions, the type of house and the type of floor and walls.

2. The study demonstrated an increase in radon concentrations in the air in homes in the Southern part of the country, with the average value per area constituting $330.3 \mathrm{~Bq} / \mathrm{m}^{3}$, followed by the Center area-253.8 Bq $/ \mathrm{m}^{3}$ and Northern area-237.9 Bq/ $\mathrm{m}^{3}$.

3. The study of the variability of radon concentration in the air of dwellings placed in different geographical districts of the Republic of Moldova revealed increased values in the Căușeni district and the lowest ones in the Chisinau municipality.

4. The research shows that the average concentration of radon in dwellings was higher in rural areas $\left(261.6 \mathrm{~Bq} / \mathrm{m}^{3}\right)$ compared to urban ones $\left(243 \mathrm{~Bq} / \mathrm{m}^{3}\right)$.

5. Through the cluster analysis, the interactions within the relationships "radon concentration $\times$ incidence/prevalence of non-communicable diseases" (Figure 7) and radon $\times$ oncological maladies interaction (Figure 8) were established. The overlapping of maps of the incidence of bronchopulmonary cancer and radon concentrations on the territory of the country (Figure 9) has shown partial interaction between these two factors, which indicates that the onset of bronchopulmonary cancer under the action of radon is a cumulative effect, determined by long-term chronic exposure and also influenced by other factors such as smoking, exogenous factors, etc.

6. Mapping radon concentrations in the air of homes across the country will be useful for legislators and construction specialists to select land for the construction of buildings, resulting in a diminished radon hazard.

Author Contributions: Conceptualization, L.C. and A.E.; Formal analysis, A.A.; Funding acquisition, A.E.; Investigation, L.C. and A.A.; Methodology, L.C. and A.A.; Project administration, L.C.; Resources, L.C.; Software, L.C. and A.E.; Supervision, L.C. and A.E.; Validation, L.C.; Visualization, L.C.; Writing—original draft, L.C., A.E. and A.A.; Writing—review and editing, A.E. All authors have read and agreed to the published version of the manuscript.

Funding: The APC was funded by "Dunarea de Jos" University of Galati, Romania, grant no. RF $3621 / 2021$.

Institutional Review Board Statement: Not applicable.

Informed Consent Statement: Not applicable.

Data Availability Statement: The data that support the findings of this study are available from the first (L.C.) and corresponding (A.E.) authors upon reasonable request.

Acknowledgments: The research was carried out within the framework of the MOL9007 project, supported by the International Atomic Energy Agency (IAEA), Vienna, Austria. We thank the project coordinators and experts of the IAEA, Ludmila Wiszczor, Olga German and Marcus Hoffmann. The work of the author Antoaneta Ene was financed by the Dunarea de Jos University of Galati through the internal grant with contract no. RF 3621/2021 and by the project with the code BSB 27-MONITOX (2018-2021), financed by the European Union through the Joint Operational Programme Black Sea Basin 2014-2020.

Conflicts of Interest: The authors declare no conflict of interest.

\section{References}

1. UNSCEAR Volume I, Sources and Effects of Ionizing Radiation. In United Nations Scientific Committee on the Effect of Atomic Radiation, 2008; United Nations: New York, NY, USA, 2010.

2. Coretchi, L.; Bahnarel, I.; Gîncu, M.; Cojocari, A.; Hoffmann, M. Controlul și evaluarea riscului expunerii populației la radon în Republica Moldova. OHERM 2020, 1, 42-49. [CrossRef]

3. Lantz, P.; Mendez, D.; Philbert, M. Radon, Smoking, and Lung Cancer: The need to refocus radon control policy. Am. J. Public Health 2013, 103, 443-447. [CrossRef] [PubMed]

4. Medaglia, F. Exposure to Radon Increases Your Risk for Lung Cancer. Mass Public Health Blog. Promoting Public Health \& Wellness in Massachusetts. 2017. Available online: https://blog.mass.gov/publichealth/environmental-health/exposure-toRadon-increases-your-risk-for-lung-cancer/ (accessed on 10 April 2021). 
5. Song, G.; Zhang, B.; Wang, X.; Gong, J.; Chan, D.; Bernett, J.; Lee, S.C. Indoor radon levels in selected hot spring hotels in Guangdong, China. Sci. Total Environ. 2005, 339, 63-70. [CrossRef] [PubMed]

6. Scott, B.R. Residential Radon Appears to Prevent Lung Cancer. Dose Response 2011, 9, 444-464. [CrossRef] [PubMed]

7. Vuchkov, D.; Ivanova, K.; Stojanovska, Z.; Kunovska, B.; Badulin, V. Radon measurement in schools and kindergartens (Kremikovtsi municipality, Bulgaria). Rom. J. Phys. 2012, 58, S328-S335.

8. Ferlay, J.; Colombet, M.; Soerjomataram, I.; Dyba, T.; Randi, G.; Bettio, M.; Gavin, A.; Visser, O.; Bray, F. Cancer incidence and mortality patterns in Europe: Estimates for 40 countries and 25 major cancers in 2018. Eur. J. Cancer 2018, 103, 356-387. [CrossRef] [PubMed]

9. Lofstedt, R. The communication of radon risk in Sweden: Where are we and where are we going? J. Risk Res. 2019, $22,773-781$. [CrossRef]

10. Khan, S.M.; Gomes, J. An Interdisciplinary Population Health Approach to the Radon Health Risk Management in Canada. Interdiscip. J. Health Sci. 2017, 3, 32-43. Available online: https://ruor.uottawa.ca/bitstream/10393/37336/1/RISS-IJHS5\%287.1 \%29---FINAL-PDF-32-43.pdf (accessed on 10 April 2021). [CrossRef]

11. Biblin, A. Development of the model of radiation risk-communication with the public for the arrangement of the research Radiatsionnaya Gygiena Radiat. Hyg. 2019, 12, 74-84. [CrossRef]

12. WHO. WHO Handbook on Indoor Radon: A Public Health Perspective; Zeeb, H., Shannoun, F., Eds.; World Health Organization: Geneva, Switzerland, 2009; ISBN 978-92-4-154767.

13. EU. Council Directive 2013/59/Euratom. Off. J. Eur. Commun. 2014, L13, 1-73. [CrossRef]

14. European Commission, Joint Research Center, Radioactivity Environmental Monitoring, European Indoor Radon Map. Available online: https: / / remap.jrc.ec.europa.eu/Atlas.aspx\# (accessed on 1 October 2021).

15. Fundamental Norms of Radiation Protection, Requirements and Hygienic Rules (NFRP-2000) no. 06.5.3.34 of 27.02.2001; Official Monitor of the Republic of Moldova no.40-41, 2001: Chisinau, Moldova, 2001.

16. RMS no. 217: Regulation and Hygienic Norms on the Regulation of Radiation Exposure of the Population from Natural Sources no.06-5.3.35 of 05.03.2001; Official Monitor of the Republic of Moldova no.92 of 03.08.2001: Kishinev, Moldova, 2001.

17. Coretchi, L.; Bahnarel, I.; Vîrlan, S.; Apostol, I. Controlul, Reglementarea și Remedierea Expunerii la Radon a Populației Republicii Moldova; Tipografia "Sirius": Chişinău, Moldova, 2020; pp. 60-77. ISBN 978-9975-57-290-3. 